\title{
Effects of Feeding Different Levels on Digestibility Body Weight Body Condition Score and Stool Quality in Dogs
}

\author{
Oğuzhan KAHRAMAN1*, Fatma İNAL', Zekeriya Safa İNANÇ1 \\ ${ }^{1}$ Selcuk University, Faculty of Veterinary Medicine, Department of Animal Nutrition and Nutritionial Diseases, 42025, Konya, Turkey
}

\begin{abstract}
In this study, effects of different levels of feeding on digestibility, body weight(BW), body condition score(BCS) and some stool parameters were investigated. Fifteen adult Golden Retriever dogs were divided into 3 groups. ME content of food and ME requirements of the dogs were determined by the modified Atwater factors and the FEDIAF equation $\left(95 * \mathrm{BW}^{0.75}\right)$. The first group was fed $50 \%$ less than daily metabolic energy requirement(MER)(1), second group was fed 100\%(2) and the third group was fed 50\% more than the MER(3). Trial lasted 15 days. Stools were scored and stool samples were taken in last 4 days of the study. Dry matter(DMD) and organic matter digestibilities(OMD) were determined by acid-insoluble ash indicator method. BW and BCS values were determined on the 7th and 15th days. Changes in $\mathrm{BW}$ and $\mathrm{BCS}$ between days and groups were insignificant $(\mathrm{P}>0.05)$. DMD and $\mathrm{OMD}$ values were the highest in groups 1 and $2(\mathrm{P}<0.05)$. Group 1 had the highest stool score $(\mathrm{P}<0.05)$. There was no significant difference in stool $\mathrm{DM}$ levels between all groups $(\mathrm{P}>0.05)$. In conclusion, modified Atwater factors and formula $95 * \mathrm{BW}{ }^{0.75}$ were sufficient to preserve $\mathrm{BW}$ and $\mathrm{BCS}$ for this 15-day study. More studies are needed to compare the different formulas used to calculate the energy needs of dogs and the energy content in their diets. BW and BCS changes should be demonstrated with long-term trials. Effects of daily amount of food determined by the formulas on digestibility and health of dogs should also be investigated.
\end{abstract}

Keywords: Atwater factors, body condition score, digestibility, dog, metabolizable energy $* * *$

\section{Farkı Düzeylerde Beslemenin Köpeklerde Sindirilebilirlik Canlı ağırlık Vücut Kondüsyon Skoru ve Dışkı Kalitesi Üzerine Etkileri}

\section{ÖZ}

Bu çalışmada farklı düzeylerde beslemenin sindirilebilirlik, canlı ağıllık(CA), vücut kondüsyon skoru(VKS) ve bazı dışkı parametreleri üzerine etkileri araştırıldı. Onbeş yetişkin Golden Retriever köpek 3 gruba ayrıldı. Mamanın ME içeriği ve köpeklerin ME gereksinimleri, modifiye Atwater faktörleri ve FEDIAF denklemi $\left(95^{*} \mathrm{CA}^{0.75}\right)$ ile belirlendi. Birinci grup günlük metabolik enerji ihtiyacından(MEİ) \%50 daha az(1), ikinci grup ihtiyacın \%100’ü(2) ve üçüncü grup MEİ(3)'dan \%50 daha fazla olacak düzeyde beslendi. Deneme 15 gün sürdü. Çalışmanın son 4 gününde dışkı skorlaması yapıldı ve dışkı numuneleri alındı. Kuru madde(KMS) ve organik madde sindirilebilirliği(OMS) asitte çözünmeyen kül indikatör yöntemi ile belirlendi. CA ve VKS değerlerindeki değişimler 7. ve 15. günlerde belirlendi. Günler ve gruplar arasındaki CA ve VKS değişiklikleri önemsizdi(P $>0.05)$. KMS ve OMS değerleri grup 1 ve 2 'de en yüksekti( $(\mathrm{P}<0.05)$. Grup 1 en yüksek dışkı skoruna sahipti $(\mathrm{P}<0.05)$. Her üç grubun dışkı KM düzeyleri arasında anlamlı bir fark yoktu( $\mathrm{P}>0.05)$. Sonuç olarak, 15 gün süren bu çalışma için modifiye Atwater faktörleri ve $95^{*} C A^{0.75}$ formülü CA ve VKS'yi korumada yeterliydi. Köpeklerin enerji ihtiyaçlarını ve diyetlerindeki enerji içeriğini hesaplamada kullanılan farklı formüllerin karşılaştırılmalı olarak değerlendirildiği daha fazla çalışmaya ihtiyaç vardır. CA ve VKS'ye etkileri uzun süren denemelerle ortaya konulmalıdır. Formüllerle belirlenen günlük mama miktarının köpeklerde sindirilebilirlik ve sağlı̆̆a etkileri de araştırılmalıdır.

Anahtar Kelimeler: Atwater faktörleri, köpek, sindirilebilirlik, metabolik enerji, vücut kondisyon skoru

To cite this article: Kahraman O. Inal F. Inanc Z.S. Effects of Feeding Different Levels on Digestibility Body Weight Body Condition Score and Stool Quality in Dogs. Kocatepe Vet J. (2022):15(1): 106-114

Submission: 05.11.2021 Accepted: 22.02.2022 Published Online: 28.02.2022

ORCID ID; OK: 0000-0002-9315-5276, Fi: 0000-0002-5022-1579, ZSİ: 0000-0003-0832-9209

*Corresponding author e-mail: vetoguzhan90@gmail.com 


\section{INTRODUCTION}

The energy levels of the food is important as the food intake is basicly controlled by energy density of dog food or diets. Therefore, all the other nutrients in the food should be relative to the energy content (Abinaya et al. 2020). Determining metabolizable energy requirements(MER) of dogs is an important topic for pet food brands and manufacturers. Accurate data on MER of dogs allows to ensure giving accurate feeding recommendations on packaging, ensures advising customers correctly and also plays a role in animal welfare. The energy density of dog foods determines the amount of food need to be given and consequently, knowledge of food energy content is critical for the reliable usage of commercial dog foods (Castrillo et al. 2009).

It has long been established that energy requirements vary considerably from pet to pet, with factors such as activity level, breed, sex, neuter status, age, health status, temperament, body size, insulation characteristics of skin and coat, in addition to environmental factors such as housing conditions and ambient temperature all having an effect (Lund et al. 2005, German 2006, Cameron et al. 2011). Suppling energy has great importance for dogs in determining nutritive value of the food. Dogs, like other animals get their energy by partial and complete oxidation of organic molecules absorbed from the diets and tissue catabolism (Pond et al. 2005). The term of metabolizable energy (ME) is commonly used to express energy density of dog foods. The energy density of food or diet determines the amount of food need to be given daily. Therefore, food energy content is critical for the reliable usage of different kind of commercial dog foods. Energy density of food determines the concentration of other nutrients (amino acids, minerals, vitamins) must have in order to provide animals requirements (Castrillo et al. 2009). Generally ME content of commercial dry dog foods for adult dogs is varied from 3178 to $4405 \mathrm{kcal} / \mathrm{kg}$ (Hodgkinson et al. 2008).

Determining the energy requirements of pet dogs is also a particular challenge, since data from other populations, particularly those from dogs in kennelled environments, are not representative. Based upon available literature, maintenance energy requirements for adult dogs varied between 95 and $200 \mathrm{kcal} / \mathrm{kg}^{0.75}$ depending on breed, level of activity or husbandry type (Bermingham et al. 2014, FEDIAF 2020).

Overfeeding is a growing underrated problem in dog nutrition all over the world. It has many connections leading not only obesity but also many metabolic disorders in dogs (Meyer et al. 1999). It is estimated that approximately $40-45 \%$ of pet dogs are overweight or obese and this rate is increasing. This is associated with medical disorders which significantly reduce life span and quality. Being overweight in dogs is generally because of too much food being offered (German 2006, Courcier et al. 2010). It is

important to note that dog owners tend to underestimate the body condition of obese dogs (Colliard et al. 2006) even though dogs start to gain weight, their owners will continue to overfeed (Hodgkinson et al. 2008).

Although it is known that under and overfeeding has negative effects in dog's health, studies about their effects on digestibility and stool quality are scarce. ME measurements of $\operatorname{dog}$ foods are not practical or financially feasible; therefore, accepted modified Atwater equations are used to predict ME and develop feeding guidelines (Asaro et al. 2017). There are different equations for predicting ME for dogs but effects of these equations are not well determined. Atwater equations do not account for fiber or energy digestibility, so predicted ME values could differ. Therefore aim of this study was to evaluate modified Atwater equations for determination of ME density of dog food and FEDIAF equation of MER of dogs. Also, it was aimed to determine the effects of feeding at different levels on digestibility, body weight(BW), body condition score(BCS) and stool quality in dogs.

\section{MATERIALS AND METHODS}

\section{Dogs and Trial Design}

Fifteen adult (age $=$ 5-6 years, body weight $=24.5 \pm 1.5 \mathrm{~kg}$ ) Golden retriever dogs (6 male, 9 female) were used for the present study. Dogs were divided into 3 groups as having same number of female-male and similar average BW. They were housed in the individual concrete kennels with a closed $(190 \times 190 \mathrm{~cm})$ and open area $(510 \times 230 \mathrm{~cm})$ in XXX According to the calculated $\mathrm{ME}$ requirement for maintenance, daily required food was given to the 1st group at the level of 50\% less than MER, 100\% (full requirement) for the 2nd and 50\% more than MER for the 3 rd group. The trial was continued for 15 days.

\section{Chemical Analyses and Calculation of Amount of Food}

One commercial dry dog food was used and it's nutrient composition was given in Table 1. Dry matter $(\mathrm{DM})$, crude ash (CA), ether extraction (EE), crude fiber (CF) and crude protein (CP) analyzes were performed according to AOAC (2003) methods. In order to determine digestibility, DM and CA analyzes were also performed on the collected faeces. The energy content of the food was determined by calculations of modified Atwater factors (FEDIAF 2020). The ME requirements of an adult dog at maintenance was calculated using the equation presented by FEDIAF (2020) as follows: 
$\mathrm{ME}(\mathrm{kcal} / \mathrm{kg})=95 \times \mathrm{W}^{0.75}$, where $\mathrm{W}$ represents body weight.

Energy content of the dog food used in the experiment calculated by nutrient analysis and the daily energy requirement for maintenance of the dogs. Amounts food given were determined with the following formulas:

$\mathrm{ME}$ in food $(\mathrm{kcal} / \mathrm{kg})=\% \mathrm{CP} * 3.5+\% \mathrm{EE} * 8.5+\mathrm{NFE} * 3.5$ (Modified Atwater factors)

Amount of food given $(\mathrm{gr})=\frac{\text { Dog's requirement }(\mathrm{ME}) * 1000}{\text { Food's ME density }(\mathrm{kcal} / \mathrm{kg})}$

$\mathrm{BW}=$ Body weight, $\mathrm{CP}=$ Crude protein, $\mathrm{EE}=$ Ether exraction, $\mathrm{NFE}, \%=100-\mathrm{CP}(\%)-\mathrm{EE}(\%)-\mathrm{CF}(\%)-\mathrm{CA}(\%)$-moisture $(\%)$

\section{Determination of Digestibility}

Clean drinking water was provided ad libitum in closed part of the individual kennels. Stool samples were stored in a deep freezer $\left(-18^{\circ} \mathrm{C}\right)$ for later analysis. Method of Alvarenga et al. (2019) was used to determine digestibility. Acid-insoluble ash(AIA) in feces and food was evaluated as an indicator. After the feces of each dog were dissolved, they were mixed and sampled for digestibility analysis. Feces were dried at $55^{\circ} \mathrm{C}$ for 48 hours in drying oven(VWR,Venti-line, USA) and ground in laboratory mill(Retsch SM100,Germany), after determining the stool dry matter(SDM) levels. Samples of $3 g$ of dry feces and 10 $\mathrm{g}$ of food were weighed in tared porcelain crucibles and burned in a furnace (Gerhardt,Germany) at $600^{\circ} \mathrm{C}$ for 8 hours. They were then boiled in $2 \mathrm{~N}$ hydrochloric acid. After this treatment, samples passed through ashless filter paper (541: Whatman, Maidstone, UK) and reburned at $600^{\circ} \mathrm{C}$ overnight (approximately 12 hours). The samples were weighed after the second burning to determine the percent of AIA. Digestibility was determined by AIA in 2 parallels in all 5 dogs in the three groups. The formulas given below were used to determine AIA and digestibility.

$$
\text { AIA, } \%=\frac{(c-a) \times 100}{b}
$$

$\mathrm{a}=$ tare of ash pots, $\mathrm{b}=$ weight of stool and food, $\mathrm{c}=$ sample remaining after the second burning

$$
\text { Digestibility, } \%=100-100 \times \frac{\% \text { AIA in food }}{\% \text { AIA in feces }}
$$

\section{Determination of Body Weight and Body Condition Score}

Dogs were weighed on the first, 7th and 15th days of trial (ERTE, model B1, Turkey). The BCS evaluation was based on visual assessment and palpation according to a 9 point scale system (Laflamme, 1997). Four classes of BCS were considered in this trial as follows:

BCS 1 to $3=$ lean dog; BCS $4-5=$ ideal dog; BCS $6-7=$ overweight dog; and BCS $\geq 8=$ obese dog.

\section{Determination of Stool Consistency Score}

Stool consistency scoring was performed by 4 different researchers just before stool collection in the last 4 days of the trial. Stool consistencies were scored by following 1-5 system. According to this system, stools are scored by their appearance and consistency. Properly shaped and hard-consistent stools are considered high quality.

1. diarrhea-like stool, 2. soft and slightly shaped stool, 3. soft, shaped, moist and leaving marks of stool on the floor, 4. well-formed stool, non-dissolving and leaving no traces on the floor, 5. very well-formed and dry looking stools (Strickling et al. 2000).

\section{Statistical Analysis}

SPSS 22 (IBM Corp. Released 2013. IBM SPSS Statistics for Windows, Version 22.0. Armonk, NY): IBM Corp) statistics package program was used. Oneway ANOVA tests were performed on BW and BCS changes, DMD, OMD, SDM and fecal consistency scores(FCS) data. Also Independent t-test (Student's ttest) test was used to compare three groups and if not met with the prerequisites, then the Bonferroni-Dunn test was performed to compare the means of the groups for all parameters examined. Values of $\mathrm{P}<0.05$ were considered statistically significant.

\section{RESULTS}

Dry matter (DMD) and organic matter digestibilities (OMD) of tested food were the highest in group 1 (DMD:73.49\%, OMD:77.8\%) and 2 (DMD:72.37\%, OMD:78.86\%) $\mathrm{P}<0.05$. Dog group 3 which, fed 50\% more than MER ate all dog food given in fifteen minutes and no refusal was recorded. This group showed the lowest DMD (68.29\%) and OMD (72.95\%) (Table 2).

Dogs consumed all of their calculated amount of the food and maintained a good health throughout the study. Determined BW and BCS changes were not significant between groups and days (Table 3,4).

Results of fecal consistency score and stool dry matter were given in Table 5. There was a difference between the groups in terms of fecal scores $(\mathrm{P}<0.05)$. It was determined that the stools of the dogs in the 1st group, which ate $50 \%$ less food than they needed, had a harder consistency $(\mathrm{P}<0.05)$. There was no difference between the groups in stool dry matter levels. 
Table 1. Nutrient Composition of Commercial Dry Food Fed to Dogs (\%DM)

\begin{tabular}{lc}
\hline Composition & \\
\hline Dry matter,\% & 95.95 \\
Crude ash,\% & 10.64 \\
Ether extraction, \% & 8.96 \\
Crude fiber, \% & 9.92 \\
Crude protein,\% & 20.07 \\
ME,kcal/kg* & 3142.65 \\
\hline
\end{tabular}

*: Calculated value

Table 2. Dry matter and organic matter digestibilities of groups, $\%$

\begin{tabular}{llllll}
\hline & Groups & $\mathrm{N}$ & $\bar{x}$ & SEM & $P$-value \\
\hline \multirow{3}{*}{ DMD } & 1 & 10 & $73.49^{\mathrm{a}}$ & 0.5 & \\
& 2 & 10 & $72.37^{\mathrm{a}}$ & 0.6 & 0.004 \\
& 3 & 10 & $68.29^{\mathrm{b}}$ & 1.12 & \\
\multirow{3}{*}{ OMD } & 1 & 10 & $77.8^{\mathrm{a}}$ & 0.35 & \\
& 2 & 10 & $76.86^{\mathrm{a}}$ & 0.47 & 0.004 \\
& 3 & 10 & $72.95^{\mathrm{b}}$ & 0.94 & \\
\hline
\end{tabular}

$\mathrm{DMD}=$ Dry matter digestibility, $\mathrm{OMD}=$ Organic matter digestibility, SEM= Standart error of means

$1=$ Group of dogs given $-50 \%$ less amount of food than requirement of daily metabolizable energy of maintenance $2=$ Group of dogs given $100 \%$ amount of food of daily metabolizable energy of maintenance

$3=$ Group of dogs given $+50 \%$ more amount of food than requirement of daily metabolizable energy of maintenance Means in the same column having different superscripts differ significantly $(\mathrm{P}<0.05)$

Table 3. Body condition score changes of dogs given three different levels of food

\begin{tabular}{lllll}
\hline & & 1 & 2 & 3 \\
\cline { 3 - 5 } & $\mathrm{N}$ & Mean \pm SEM & Mean \pm SEM & Mean \pm SEM \\
Day 0 & 5 & $7 \pm 0.37$ & $7.3 \pm 0.53$ & $6.6 \pm 0.43$ \\
Day 7 & 5 & $6.5 \pm 0.34$ & $7.6 \pm 0.55$ & $7.2 \pm 0.33$ \\
Day 15 & 5 & $6.4 \pm 0.48$ & $7.2 \pm 0.60$ & $7.3 \pm 0.34$ \\
P-value & & 0.342 & 0.631 & 0.229 \\
\hline
\end{tabular}

$1=$ Group of dogs given $-50 \%$ less amount of food than daily metabolizable energy of maintenance

$2=$ Group of dogs given 100\% amount of food of daily metabolizable energy of maintenance

$3=$ Group of dogs given $+50 \%$ more amount of food than daily metabolizable energy of maintenance

$\mathrm{SEM}=$ Standart error of means 
Table 4. Body weight changes of dogs fed at three different levels

Levels of Metabolizable energy

requirements fed to dogs

\begin{tabular}{|c|c|c|c|c|c|c|c|}
\hline $\begin{array}{l}\text { Dogs body weight } \\
\text { parameters }\end{array}$ & $\mathrm{N}$ & $50 \% \operatorname{less}(1)$ & $100 \%(2)$ & $50 \%$ more $(3)$ & $\begin{array}{c}P \text {-value } \\
3 \text { vs } 1 \\
\end{array}$ & $\begin{array}{l}P \text {-value } \\
2 \text { vs } 1 \\
\end{array}$ & $\begin{array}{c}P \text {-value } \\
2 \text { vs } 3 \\
\end{array}$ \\
\hline & & Mean \pm SEM & Mean \pm SEM & Mean \pm SEM & & & \\
\hline Body weight day $0, \mathrm{~kg}$ & 5 & $25.82 \pm 1.02$ & $25.54 \pm 0.49$ & $24.6 \pm 1.19$ & 0.635 & 0.615 & 0.645 \\
\hline Body weight day $7, \mathrm{~kg}$ & 5 & $24.44 \pm 1.12$ & $24.76 \pm 0.45$ & $25.3 \pm 1.21$ & 0.752 & 0.772 & 0.712 \\
\hline Body weight day $15, \mathrm{~kg}$ & 5 & $23.58 \pm 1.03$ & $24.56 \pm 0.46$ & $25.74 \pm 1.18$ & 0.117 & 0.107 & 0.110 \\
\hline Body weight change day 0 to $7, \mathrm{~kg}$ & & -1.38 & -0.78 & 0.7 & & & \\
\hline Body weight change day 0 to $15, \mathrm{~kg}$ & & -2.24 & -0.98 & 1.14 & & & \\
\hline Day 0 vs day 7 & $P$-value & 0.365 & 0.378 & 0.357 & & & \\
\hline Day 0 vs day 15 & $P$-value & 0.769 & 0.786 & 0.724 & & & \\
\hline
\end{tabular}

$1=$ Group of dogs given $-50 \%$ less amount of food than daily metabolizable energy of maintenance requirement

$2=$ Group of dogs given $100 \%$ amount of food of daily metabolizable energy of maintenance requirement

$3=$ Group of dogs given $+50 \%$ more amount of food than daily metabolizable energy of maintenance requirement

SEM $=$ Standart error of means

Table 5. Fecal consistency scores(FCS) and stool dry matter(SDM) levels of dogs

\begin{tabular}{llllllll}
\hline \multirow{5}{*}{ FCS } & & $\mathrm{N}$ & $\min$ & $\max$ & SEM & $\bar{x}$ & $P$-value \\
\cline { 2 - 8 } & 1 & 60 & 3.5 & 5 & 0.06 & $4.21^{\mathrm{a}}$ & \\
& 2 & 60 & 3.5 & 5 & 0.05 & $4.05^{\mathrm{b}}$ & 0.032 \\
& 3 & 60 & 3 & 5 & 0.82 & $3.96^{\mathrm{b}}$ & \\
\hline \multirow{3}{*}{$\mathrm{SDM}$} & 1 & 5 & & & 1.52 & 37.46 & \\
& 2 & 5 & & & 1.46 & 37.82 & 0.892 \\
& 3 & 5 & & & 1.73 & 39.46 & \\
\hline
\end{tabular}

$1=$ Group of dogs given $-50 \%$ less amount of food than daily metabolizable energy of maintenance requirement $2=$ Group of dogs given $100 \%$ amount of food of daily metabolizable energy of maintenance requirement

$3=$ Group of dogs given $+50 \%$ more amount of food than daily metabolizable energy of maintenance requirement

$\mathrm{SEM}=$ Standart error of means

Means in the same column having different superscripts differ significantly $(\mathrm{P}<0.05)$

\section{DISCUSSION AND CONCLUSION}

Total collection of feces and urine is the most accurate method for ME determination for dogs (Laflamme 2001, Case et al. 2011). Collection of the feces is, however complicated for dogs, and requires the dog to be maintained immobile during the process, which has animal welfare implications (Hodgkinson et al. 2008). Also, caprophagia and stepping on feces can be seen in dogs kept in kennels, which cause problems in feces collection process. Thus, AIA indicator method was used in this study for digestibility determination. Variations can be high when determining digestibility with AIA method in low ash content feedstuffs (Alvarenga et al 2019). Therefore, it is difficult to interpret the data. There is sufficient ash in the food prepared for this study $(9.92 \%)$. It has been concluded in many studies that the digestibility determination in dogs with the AIA method is reliable (Zanatta et al. 2013, Alvarenga et al. 2019, Kahraman et al. 2021). Dry matter (DMD) and organic matter digestibilities (OMD) of tested food were the highest in groups given $50 \%$ less than daily MER (DMD:73.49\%, OMD:77.8\%) and total MER (DMD:72.37\%, OMD:78.86\%). Digestibility of dog foods should be more than $80 \%$, values less than $75 \%$ are not recommended (Malca et al. 2006). Dogs fed 50\% more than MER showed the lowest DMD $(68.29 \%)$ and OMD (72.95\%). Besides estimated amount of food given, this can be explain by increased transit time of food. In 50\% less than MER given dogs showed similar DMD and OMD with 100\% of MER given dogs. Fiber level in this dog food may be the reason of this result. Because satiey of dogs might increased by fiber (Pappas et al. 1989). Reduced transit time and high ileal digestibility might caused same digestibilitiy results in 50\% less than MER given dogs with $100 \%$ of MER given group. There are not scientific data about effects on direct food restriction on digestibility other than BW and body composition in dogs.

Total dietary fiber could contain high levels of insoluble fiber fraction, so that increased volume and frequency of bowel movements could be reason of low 
digestibility coefficients (Prola et al. 2010). DMD and OMD of dry food used were not high even given at the MER and \%50 less than MER. Reason of low digestibility was probably high level of CF in used dog food $(9.92 \%)$. Pet foods have fiber ranges form 0.61 to $9.40 \%$ (Hervera et al. 2007). It is the most responsible nutrient that reduces digestibility and energy content of food. High levels of fiber decreases transit time of food and digestibility in dogs (Duque-Saldarriaga et al. 2017). In a study dogs switched from a diet containing $0.6 \%$ to $14.7 \%$ of CF, DMD was reduced from $90 \%$ to $70 \%$ (Burrows et al. 1982). El-Wahab et al (2021) determined no difference of digestibility of foods contain CF levels between 1.7-2.1\%. They concluded that $\mathrm{CF}$ was not enough to affect digestibility. Similar to this study, Brambillasca et al (2010) fed dogs with $3.33 \%$ and $9.46 \% \mathrm{CF}$ content. They found lower $\operatorname{DMD}(71 \%)$ and $\operatorname{OMD}(75.5 \%)$ in $9.46 \% \quad \mathrm{CF}$ containing food.

Abinaya et al. (2020) fed dogs with three different energy levels containing foods (3021, 2697 and $2358 \mathrm{kcal} / \mathrm{kg}$ food). They fed dogs ad libitum for 20 minutes. They reported higher DMD coefficient in high energy density food (3021 kcal/kg). Reason of this was probably lower CF and crude ash content of high energy food they used. They concluded that reduced DMD was compensated with higher DM intake of foods with lower energy density. ME of food used in this study was $3142.65 \mathrm{kcal} / \mathrm{kg}$ calculated by modified Atwater factors. 50\% more MER given group's DM intake(DMI) was $20.06 \mathrm{gr} / \mathrm{kg} \mathrm{BW}$ and $100 \%$ of MER given group's was $13.43 \mathrm{gr} / \mathrm{kg} \mathrm{BW}$ in this study and dogs left no food in 20 minutes. Carciofi et al (2009) and Sa et al (2013) determined DMI of $16 \mathrm{~g} / \mathrm{kg}$ BW in adult dogs. They estimated the amount of food with the energy value of food and energy requirement of the animal, according to NRC (2006). Case et al (2011) and Laflamme (2001) also indicated that the modified Atwater calculation has shown underestimate prediction of $\mathrm{ME}$ of highly digestible diets and overestimate $\mathrm{ME}$ of those with lower digestibility. In that case, maybe daily given amount of food was not accurate for dogs used in this study for better digestibility.

Soluable and insoluable fiber fractions of dog food was not determined in this study. But it has been demonstrated that soluble fiber increases DMD (De Godoy et al. 2013). On the other hand, dog foods with CF content above $8 \%$ and a high level of fermentable non-starch polysaccharides (NSP) in the CF fraction leads underestimate prediction of energy density by modified Atwater equations (FEDIAF, 2020). NSP fraction of fiber also was not determined in this study. NRC suggests 4 step equations starts with $(5.7 \mathrm{x} \%$ protein $)+(9.4 \times \%$ fat $)+[4.1 \times(\% \mathrm{NFE}+\%$ crude fibre)] calculating gross energy and there are 3 more steps to calculate ME. But modified Atwater factors suggest equation of $\% \mathrm{CP} \times 3.5+\% \mathrm{EE}$ (fat) $\times 8.5+$ $\%$ NFE x 3.5 (AAFCO, 2008). They are based on an average digestibility of $90 \%$ for fat, $85 \%$ for carbohydrate (NFE) and 80\% for protein. Different equations did not compare with each other in this study. More studies are needed to assess equations for $\mathrm{ME}$ estimation of dog foods and longer feeding trials to determine their effects on BW and BSC. Soluable fiber fractions need to be determined for further studies to interpret their effects on digestibility, BW and BSC.

Dogs were kept in individial kennels which have open and closed parts and they were not allowed to run or take a walk. This was probably one of the reasons of being no digestibility coefficient difference between 1 st and 2nd groups. The exact ME requirements of an individual dog will depend on its age, activity level, body condition, hair (insulating conditions), environmental temperature, acclimatization, external environmental circumstances and psychological temperament (NRC 2006). Type of husbandary has an important effect for MER estimation (Bermingham et al. 2014). Activity level was considered as"low"when calculate MER with $95 \mathrm{kcal}^{*} \mathrm{BW}^{0,75}$ in this study. The equation of $95 \mathrm{kcal}^{*} \mathrm{BW} W^{0,75}$ maybe was not the best choice for the dogs kept in individual kennels. 95-130 $\mathrm{kcal}^{*} \mathrm{BW}^{0,75}$ is recommended for low active dogs. But Individually housed dogs, with little opportunity to move, may have daily energy requirements as low as 70 $\mathrm{kcal} \mathrm{ME} / \mathrm{kg}^{0.75}$ (FEDIAF 2020). Recommendations for MER may overestimate energy needs by 10 to $60 \%$ (NRC 2006). They often include a reasonable amount for activity.

Modified atwater factor and NRC equations have modarete accuracy for estimation of $\mathrm{ME}$ for wet pet foods. But NRC equations are recommened for estimation for dry dog foods (Calvez et al. 2012a). For the kibble diet, the modified Atwater calculation underestimates the ME and the NRC calculations are the most accurate predictor of ME (Tanprasertsuk et al. 2021). Furthermore, Oba et al. (2020) stated that modified Atwater factors systematically underestimate the ME content of low-fibre foods whereas they overestimate those that are high in fibre. On the other hand, Hall et al. (2013) reported that modified Atwater factors accurately predict $\mathrm{ME}$ concentrations in dog foods $\left(r^{2}=0.97\right)$. There are conflicting results but modified Atwater factors and $95 \mathrm{kcal}^{*} \mathrm{BW}^{0.75}$ equations might be the reasons of determination of low digestibility of $\mathrm{dog}$ food used in this study. More studies are needed for further investigations to determine MER of dog and ME of dry kibble foods.

Despite of low digestibility, equations used in this study seem effective to maintain BW and BSC. Calculated amount of food for dogs to maintain BW and BCS was acceptable for 15 days. Dogs started to lose weight but not significantly at the end of the trial. It can be interpreted that if this study has lasted for more than 1 month, BW changes would have been significant. Because dogs tend to lose $\% 10$ of their body weight in 1 month. Yamka et al. (2007) conducted a weight loss study lasted 2 months. They found significant change after 1 month of trial. 
Alexander et al. (2017) offered \%200 of MER to dogs and record $\% 1.25 \mathrm{BW}$ gain per week during 1 month trial. $50 \%$ more than MER given dogs gained $4.63 \%$ of initial BW end of 15 days in this study. Further studies should continue at least 1 month to determine significant $\mathrm{BW}$ changes.

The ideal BCS should be between 4/9 and 5/9 (FEDIAF, 2020). Initial BSC of dogs used in this study were between 6.6-7.3. These scores are considered overweight. MER for maintanence of dogs were calculated with inital body weights, ages and activity levels of dogs. After 15 days of trial, changes of BW and BSC scores of dogs were not significant. In some dogs calorie needs may further decrease as ansequence of an increase in subcutaneous fat (Meyer and Zentek 2005). According to Chandler (2011), loss of more than $2 \%$ of BW each week is undesirable because a greater proportion of lean body tissue loss often occurs. Saker and Remillard, (2005) used a weight loss program that estimates $\% 1-4$ of body weight loss in 1 week in dogs. They observed a poor accuracy of their weight loss program. Reasons were method and amount of food given. They used the equation of NRC suggests as $132 * \mathrm{BW}^{0.75}$ for MER of dogs. In this study $95^{*} \mathrm{BW}^{0.75}$ was used. Although it was not statistically important, $100 \%$ of MER given dogs started to lose weight after 15 days of trial. $\% 50$ more and less than daily MER given dogs were not shown any significant changes in terms of BW and BCS after 15 days of trial. These results indicates that 15 days of trial was not sufficient to determination of accuracy of modified Atwater factors. Next studies should be conducted for longer periods. Different equations are also needed to be investigated and compared to decide whether these formulas are accurate or not.

Neuter status of dogs were not considered for calculation MER. Bermingham et al (2014) reported that MER of neutered dogs lower than the requirements of intact dogs. For this study BW, age and activity levels were considered as FEDIAF (2020) suggests. As many factors affects MER, energy requirement may be below or above that suggested by NRC, AAFCO or FEDIAF and density of dog foods may need to be adjusted up or down to make sure sufficient but not excess of nutrients (Hill, 2006). In this study, ME of dog food was determined by using nutrient analysis. Quantity of the dog foods that should be fed to the animals presented on the package gives a range of quantities to take into consideration as variations between dogs. Owners often follow the recommended amounts of food labeled on the package. However, there are also obese dogs, even though they are given in the recommended amounts on the packages (Hodgkinson et al. 2008). Nuttall et al. (2017) reported that the modified Atwater factors assume constant macronutrient digestibility coefficients and have been challenged for being a source of error when calculating predicted ME.
Tanprasertsuk et al. (2021) indicated that, modified Atwater calculation underestimates the ME and NRC (2006) calculation is the most accurate predictor of ME for the kibble diets of dogs. Calculated ME of dog food used in this study was $3142.65 \mathrm{kcal} / \mathrm{kg}$. Hodgkinson et al (2008) used a commercial dog food with $2916 \mathrm{kcal} / \mathrm{kg}$ ME. They observed less BW gain. Researchers emphasized that low calorie foods should contain less than $3100 \mathrm{kcal} / \mathrm{kg}$ ME. The food used in this study was nearly a low calorie food. That could be another reason of insignificant BW gain in the group given 50\% more than MER. Hodgkinson et al. (2008) used $1.2 *\left(132 * \mathrm{BW}^{0.75}\right)$ as NRC recommended. In this study $95 * \mathrm{BW}^{0.75}$ was used. This equation can be also considered another reason of insignificant changes in BW and BSC in all three groups. In a study, less adiposity was determined in $25 \%$ food restricted dogs (Kealy et al. 2002). Dog food used in this study had sufficient nutrient content as FEDIAF(2020) recommend. Being more than $8 \%$ fiber content may be another reason of insignificant changes for BW and BCS.

Some studies have shown that high fiber content reduces stool quality (Sunvold et al. 1995b, Wichert et al. 2002). In this study, no significant difference was found between the groups in terms of fecal score and stool dry matter parameters. Fecal scores of all groups were better than ideal range (3-4) (Inal et al. 2017). There was no difference even in dogs consumed $50 \%$ more or less of their daily MER. This might may be an indication that the formulas used are inaccurate. There are not scientific data focus on stool quality and modified Atwater factors relationships. Higher CF levels could cause wet and soft stool excreation in dogs (Brambillasca et al. 2010). Fecal consistency scores were not soft in this study even dog food had $9.92 \%$ $\mathrm{CF}$. This result may be related to fiber fractions of dog food used or it may be equaiton used for determination of MER of dogs $\left(95^{*} \mathrm{BW}^{0.75}\right)$.

In conclusion, understanding energy density of dog foods enables the development of accurate feeding programs that allow to be fed with the total recommended daily energy requirement. Accurate feeding guides help to avoid under and overfeeding. Although further studies are required, the present study indicates that the combination of modified Atwater method and $95 * \mathrm{BW} 0.75$ formula for estimation dog's MER, might not adequate for the food tested here. BSC and BW changes were not significant as expected at the end of 15 days trial. But relationship of low digestibility of the food with these formulas need to be investigated. Nutrient and energy contents labeled on commercial dog food packages should be evaluated in all brands. The effects of amount of food recommended by manufacturers on BW and BCS of the dogs should be determined and checked for digestibility as well. From the dog-owner and veterinary point of view, this study highlights the 
importance of adjusting the quantities of dog foods that should be fed according to the body condition of the dog. Each dog's feeding program should be assessed routinely and adjustments made based on the animal's life stage and general health. This study provides scientific information to veterinarians, nutritionists, pet food manufacturers, and pet owners in understanding the importance of energy density of dog foods and energy requirements of dogs.

Ethics Committee Information: The presented study was carried out with the approval and permission of Selcuk University Veterinary Faculty Experimental Animal Production and Research Center Impact Committee with the decision number 2021/106 dated 20.10.2021. In addition, the authors declared that they comply with the Research and Publication Ethics.

Conflict of Interest: The authors declared that there are no actual, potential or perceived conflicts of interest for this article.

Financial support: No financial support was received for this study.

Explanation: It was presented as a summary paper at the EDUVET international congress of veterinary sciences (25-27 June 2021).

\section{REFERENCES}

AAFCO. Association of American Feed Control Officials. Official Publications of Association of American Feed Control Officials Incorporated. 2008; AAFCO, Atlanta, GA, USA.

Abinaya P, Ally K, Ananth D, Purushothaman S, Gleeja VL. Effect of feeding diet with graded levels of energy on digestibility and dry matter intake in adult medium sized nondescript dogs. J Vet Anim Sci. 2020; 51(1): 61-64.

Alexander C, Liu TW, Devendran S, Theis S, Ridlon JM, Suchodolski JS, Swanson KS. Effects of prebiotic inulintype fructans on blood metabolite and hormone concentrations and fecal microbiota and bile acids in overweight dogs. The FASEB Journal. 2017; 31: 965-13.

Alvarenga IC, Aldrich CG, Ou Z. Comparison of four digestibility markers to estimate fecal output of dogs. J Anım Sci. 2019; 97(3): 1036-1041.

AOAC. Association of Official Analytical Chemists Official Methods of Analysis. 2003; 15th ed.

Asaro NJ, Guevara MA, Berendt K, Zijlstra R, Shoveller AK. Digestibility is similar between commercial diets that provide ingredients with different perceived glycemic responses and the inaccuracy of using the modified atwater calculation to calculate metabolizable energy. Vet Sci. 2017; 4(4): 54.

Bermingham EN, Thomas DG, Cave NJ, Morris PJ, Butterwick RF, German AJ. Energy requirements of adult dogs: a meta-analysis. PloS one. 2014; 9(10): e109681.

Brambillasca S, Purtscher F, Britos A, Repetto JL, Cajarville C. Digestibility, fecal characteristics, and plasma glucose and urea in dogs fed a commercial dog food once or three times daily. Can Vet J. 2010; 51(2): 190.
Burrows CF, Kronfeld DS, Banta CA, Merritt AM. Effects of fiber on digestibility and transit time in dogs. J Nutr. 1982; 112(9): 1726-1732.

Calvez J, Biourge V, Weber M. Metabolizable energy in dry dog food is best predicted by NRC 2006 equation. 2012a; 97: In: 12 AAVN Clinical Nutrition and Research Symposium.

Carciofi AC, de-Oliveira LD, Vale'rio AG, Borges LL, de Carvalho FM, Brunetto MA, Vasconcellos RS. Comparison of micronized whole soybeans to common protein sources in dry dog and cat diets. Anim Feed Sci Technol. 2009; 151: 251-260.

Cameron KM, Morris PJ, Hackett RM, Speakman JR. The effects of increasing water content to reduce the energy density of the diet on body mass changes following caloric restriction in domestic cats. J Anim Physiol Anim Nutr. 2011; 95(3): 399-408.

Case LP, Hayeg MG, Daristotle L, Raasch MF. A Resource for Companion Animal Professionals, in: Canine and Feline Nutrition, 3rd ed., Missouri, Mosby 2011; pp. 120129.

Castrillo C, Hervera M, Baucells MD. Methods for predicting the energy value of pet foods. Rev Bras de Zootec. 2009; 38: $1-14$.

Chandler M. Strategies for management of obesity in dogs and cats. Vet Times. 2011; 41(41), 22-24.

Colliard L, Ancel J, Benet JJ, Paragon BM, Blanchard G. Risk factors for obesity in dogs in France. J Nutr. 2006; 136, 1951-1954.

Courcier EA, Thomson RM, Mellor DJ, Yam PS. An epidemiological study of environmental factors associated with canine obesity. J Small Anim Pract. 2010; 51: 362-367.

De Godoy MR, Kerr KR, Fahey Jr GC. Alternative dietary fiber sources in companion animal nutrition. Nutrients. 2013; 5(8): 3099-3117.

Duque-Saldarriaga JC, Posada-Ochoa SL; Agudelo-Trujillo JH. Assessment of energy content in dog foods. Arch Zootec. 2017; 66(254): 279-286

El-Wahab AA, Wilke V, Grone R, Visscher C. Nutrient Digestibility of a Vegetarian Diet with or without the Supplementation of Feather Meal and Either Corn Meal, Fermented Rye or Rye and Its Effect on Fecal Quality in Dogs. Anim. 2021; 11: 496.

German AJ. The growing problem of obesity in dogs and cats. J Nutr. 2006; 136: 1940S-1946S.

Hall JA, Melendez LD, Jewell DE. Using Gross Energy Improves Metabolizable Energy Predictive Equations for Pet Foods Whereas Undigested Protein and Fiber Content Predict Stool Quality. PLoS ONE. 2013; 8(1): e54405.

Hervera M, Baucells MD, Blanch F, Castrillo C. Prediction of digestible energy content of extruded dog food by in vitro analyses. J Anim Physiol Anim Nutr. 2007; 91(5-6): 205209.

Hill RC. Challenges in measuring energy expenditure in companion animals: a clinician's perspective. J Nutr. 2006; 136(7): 1967-1972.

Hodgkinson SM, Ibáñez OL, Alvarez C, Alomar D. Evaluation of the amount of metabolizable energy in the dog food quantities recommended by the manufacturers to be fed daily to dogs, in relation to their energy requirements. Arch Med Vet. 2008; 40: 251-258.

FEDIAF. Nutritional Guidelines for Complete and Complementary Pet Food for Cats and Dogs. 2020. (Fédération Européenne de l'Industrie des Aliments pour Animaux Familiers)

Inal F, Alataş MS, Kahraman O, İnal Ş, Uludağ M, Gürbüz E, Polat ES. Barley as an alternative to rice in $\operatorname{dog}$ food. Turkish J Vet Anim Sci. 2017; 41(6): 770-774. 
Kahraman O, İnal F, İnanç ZS, Pirinç A, Kucur MA. Farklı sürelerde pişirilen dengeli toz mamanın köpeklerde tercih, sindirilebilirlik ve dışkı kalitesi üzerine etkileri. Eurasian J Vet Sci. 2021; 37(1): 41-48.

Kealy RD, Lawler DF, Ballam JM, Mantz SL, Biery DN, Greeley EH, Stowe HD. Effects of diet restriction on life span and age-related changes in dogs. J Am Vet Med Assoc. 2020; 220(9): 1315-1320.

Laflamme DP. Development and validation of a body condition score system for dogs. Canine Pract. 1997; 22:10-15.

Laflamme DP. Determining metabolizable energy content in commercial pet foods. . J Anim Physiol Anim Nutr. 2001; 85(7-8): 222-230.

Lund EM, Armstrong PJ, Kirk CA, Klausner JS. Prevalence and risk factors for obesity in adult cats from private US veterinary practices. Int J Appl Res Vet Med. 2005; 3: 8896

Malca S, Lucas O, Arbaiza T, Carcelén F, San Martín F. Comparación de dos técnicas para determinar la digestibilidad proteica de insumo y alimentos comerciales para caninos. Rev Invest Vet Perú. 2006; 17: 96-103.

Meyer H, Zentek, J, Habernoll H, Maskell I. Digestibility and compatibility of mixed diets and faecal consistency in different breeds of dog. J Vet Med A. 1999; 46(3): 155-166.

Meyer H, Zentek J. Energie und Nährstoffe- Stoffwechsel und Bedarf. In: Ernährung des Hundes. 5th ed. P. Parey Verlag. 2005; pp. 49-96.

NRC. Energy. In: National Research Council, editor.Nutrient requirements of dogs and cats.2006; Washingtion DC: National Academic Press. pp.22-48

Nuttall D, Butterwick R, Strauhs K, McGenity P. Comparison of measured and predicted energy density of an oral care chew for dogs. J. Nutr. Sci. 2017: 6.

Oba PM, Utterback PL, Parsons CM, Swanson KS. True nutrient and amino acid digestibility of dog foods made with human-grade ingredients using the precision-fed cecectomized rooster assay. Transl Anim Sci. 2020; 4(1): 442-451.

Pappas TN, Melendez RL, Debas HT. Gastric distension isa physiologic satiety signal in the dog. Dig Dis Sci. 1989; 34:1489-1493.

Pond WG, Church DC, Pond, KR. Basic animal nutrition and feeding. 5th ed. John Wiley \& Sons. 2005; USA. pp. 608.

Prola L, Dobenecker B, Mussa PP, Kienzle, E. Influence of cellulose fibre length on faecal quality, mineral excretion and nutrient digestibility in cat. J Anim Physiol Anim Nutr (Berl). 2010; 94(3): 362-367.

Sa FC, Vasconcellos RS, Brunetto MA, Filho FOR, Gomes MOS, Carciofi AC. Enzyme use in kibble diets formulated with wheat bran for dogs: effects on processing and digestibility. J Anim Physiol Anim Nutr (Berl). 2013; 97: 51-59.

Saker KE, Remillard RL. Performance of a canine weight-loss program in clinical practice. Vet Ther. 2005; 6(4): 291.

Strickling JA, Harmon DL, Dawson KA, Gross KL. Evaluation of oligosaccharide addition to dog diets: influences on nutrient digestion and microbial populations. Anim Feed Sci Technol. 2000; 86(3-4): 205-219.

Sunvold GD, Fahey GC jr, Merchen NR, Titgemeyer EC, Bourquin LD, Bauer LL, Reinhart GA. Dietary fibre for dogs: IV. In vitro fermentation of selected fibre sources by dog fecal inoculum and in vivo digestion and metabolism of fiber-supplemented diets. J Anim Sci. 1995b; 73: 10991109.

Tanprasertsuk J, Perry LAM, Tate DE, Honaker RW, Shmalberg J. Apparent total tract nutrient digestibility and metabolizable energy estimation in commercial fresh and extruded dry kibble dog foods. 2021; Transl Anim Sci. 2021; 5(3):1-9.

Wichert B, Schuster S, Hofmann M, Dobenecker B, Kienzle E. Influence of different cellulose types on feces quality of dogs. J Nutr. 2002; 132(6): 1728-1729.

Yamka RM, Frantz NZ, Friesen KG. Effects of 3 canine weight loss foods on body composition and obesity markers. Int. J. Appl. Res. Vet. Med. 2007; 5(3): 125.

Zanatta CP, Gabeloni LR, Félix AP, Brito CBMD, Oliveira SGD, Maiorka A. Methodology for determination of digestibility of diets containing vegetable or animal protein sources in dogs. Ciênc Rural. 2013; 43: 696-701. 